\title{
ABUSE AND DISRESPECT IN CHILDBIRTH CARE AS A PUBLIC HEALTH ISSUE IN BRAZIL: ORIGINS, DEFINITIONS, IMPACTS ON MATERNAL HEALTH, AND PROPOSALS FOR ITS PREVENTION
}

\author{
Simone Grilo Diniz ${ }^{1}$, Heloisa de Oliveira Salgado ${ }^{1}$, Halana Faria de Aguiar Andrezzo ${ }^{1}$, \\ Paula Galdino Cardin de Carvalho ${ }^{1}$, Priscila Cavalcanti Albuquerque Carvalho' ${ }^{1}$, \\ Cláudia de Azevedo Aguiar' ${ }^{1}$, Denise Yoshie Niy ${ }^{1}$
}

\begin{abstract}
Disrespect and abuse (in Brazil called obstetric violence), described by different terms, is increasingly used in social activism, in academic research and public policy formulation, and was recently recognized as a public health issue by the World Health Organization. As an innovative theme, it requires a mapping its origins, definitions, typology, impacts on maternal health and proposals for its preventing and remedy. We present a critical-narrative review about this issue, including academic literature, productions of social movements and institutional documents, in Brazil and internationally. After a short historical overview, we map the definitions and types of violence. The complex causation of these forms of violence is discussed, including the role of professional training, the organization of health services, and the implications for maternal morbidity and mortality. Finally we present interventions in public health that have been used or proposed to prevent and mitigate obstetric violence, and an agenda for innovation and research in this area.
\end{abstract}

Keywords: humanized birth, abuse and disrespect, violence against women, gender and health, human rights, patients rights, patient safety.

\section{INTRODUCTION}

In the second decade of this century, obstetric violence became visible, being subject of numerous studies, art shows, ${ }^{1,2}$ documentaries, ${ }^{3-5}$ actions in the judiciary, 6 parliamentary investigation,7 several initiatives by the Public Prosecutor to defend women's rights ${ }^{8-12}$ as well as a new set of public health interventions. Its relevance and legitimacy as a public health problem was corroborated by the recent statement from the World Health Organization (WHO) called "The prevention and elimination of disrespect and abuse during facilitybased childbirth", ${ }^{13}$ and by the creation of the Mother and Baby-friendly Childbirth Facility Initiative. ${ }^{14}$ These innovative actions are geared to make visible, prevent and remedy this form of violence in health practices, in the public and private sectors, change the training of health providers, and to encourage governments and institutions for research and interventions.

As an innovative and recent topic, it is still surrounded by imprecisions. What is needed are therefore provisional mappings of its origins, magnitude, definitions, typology, impacts on maternal health, and proposals to address it, in order to better make justice to its importance in terms of public health.

In this critical-narrative review, we included academic literature, productions of social movements, policy documents, legal documents, in Brazil and internationally, in order to highlight different dimensions of violence in facility-based childbirth, some of its antecedents, consequences and proposals to overcome it. The goal is to introduce the reader in the debate in order to assist in the search on specific aspects that can be addressed as research and intervention issues.

\section{Abuse and disrespect (obstetric violen- ce) around the world \\ Although considered a "recent" or a "new" research theme, reports of women subjected to abusive treatment during institutionalized childbirth appear in different historical moments, albeit under different names, finding responses in different} 1 Departamento de Saúde Materno-Infantil. Faculdade de Saúde Pública da Universidade de São Paulo.
Corresponding author: Simone Grilo Diniz. E-mail: sidiniz@usp.br

Suggested citation: Diniz SG, Salgado HO, Andrezzo HFA, Carvalho PGC, Carvalho PCA, Aguiar CA, Niy DY. Abuse and disrespect in childbirth care as a public health issue in Brazil: origins, definitions, impacts on maternal health, and proposals for its prevention. Journal of Human Growth and Development. 25(3): 377-384. Doi: http://dx.doi.org/10.7322/jhgd.106080 Manuscript submitted Manuscript submitted Oct 22 2014, accepted for publication Dec 192014. 
contexts, and often having an important effect on the change of care practices in pregnancy and childbirth.

For example, by the end of the 1950s, violence in the birth narratives broke the barrier of silence in the US, when the Ladies Home Journal, a magazine for housewives, published the article "Cruelty in Maternity Wards". The text described as torture the treatment received by pregnant women, subjected to twilight sleep (a combination of morphine and scopolamine), which produced deep sedation, frequently accompanied by restlessness and possible hallucinations. Health providers used to put handcuffs and shackles on the feet and hands of patients so they do not fall from the bed, and often women postpartum had bruises on their bodies and injuries to wrists. The article also reports the injuries resulting from routine use of forceps deliveries in unconscious women. It caused a flood of letters to the magazine and other media, with similar testimonies, prompting major changes in care routines and the creation of the American Society of Psycho-prophylaxis in Obstetrics. ${ }^{15}$

In the UK in 1958, a Society for the Prevention of Cruelty to Pregnant Women was created. ${ }^{16}$ The letter that calls for its foundation, originally published in the Guardian, says:

'[...] In hospitals, [...] mothers put up with loneliness, lack of sympathy, lack of privacy, lack of consideration, poor food, unlikely visiting hours, callousness, regimentation, lack of instruction, lack of rest, deprivation of the new baby, stupidly rigid routines, rudeness, a complete disregard of mental care or the personality of the mother. Our maternity hospitals are often unhappy places with memories of unhappy experiences. [...] (1960 apud Beech; Willington, (2007) p. 2)

Feminist theorists like Adrienne Rich $^{17}$ reported her grief with the experience lived by women of higher income and education in the 1950s: "We give birth in hospitals [...] carelessly drugged and tied against our will, [...] our children removed from us until other experts tell us when we can embrace our newborn "(p. 269). The classic Our bodies, Ourselves, ${ }^{18,19}$ as well as other feminist books of the decades from 1960 to 1980, reinforced these criticisms with extensive narratives, helping to raise awareness and inspired generations of professionals and activists in the field, denouncing the irrationality of practices.

In 1998, the Latin American Center for the Rights of Women ${ }^{20}$ published the report Silencio $y$ Complicidad: Violencia contra la Mujer en los Salud de Servicios Públicos in Peru with extensive documentation of abuses of human rights of women during insitutionalized childbirth, which applies to across the continent.

\section{Obstetric violence in Brazil}

In Brazil, the issue was already being addressed in feminists in academic institutions and social movements. The pioneer research Espelho de Vênus (Venus' Mirror), by the Ceres Group
$(1981),{ }^{21}$ in the 1980 s, was an ethnography of the female experience, explicitly describing the institutionalized birth as a violent experience. This group of activists researchers published narratives demonstrating that:

It is not justin in sexuality that violence appears marking the existential trajectory of women. Also in the doctor-patient relationship, once again the ignorance of their physiology is key to explain the feelings of helplessness and hopelessness when a woman watches her body being manipulated when resorting to medicine in the most significant of his life moments: contraception, birth and abortion.(p. 349) ${ }^{21}$

In the early 90s, the action-research coordinated by the City of São Paulo, called "Violence - A Glimpse of the City" ${ }^{22}$ clearly states, with many narratives, that childbirth in institutions was described an experience of violence, and often providers had aggressive and intimidating postures, humiliated patients and did not respect their pain. Obstetric violence was also been the subject of health policy at the end of the 1980s: the Comprehensive Care Program for Women's Health (PAISM), for example, recognized the impersonal treatment and often aggressive attention to women's health. But while the subject was on the feminist agenda and even in public policy, it has been relatively neglected in the face of resistance from professionals and other pressing issues on the agenda of movements, and the problem of lack of access of poor women to essential services. Still, obstetric violence was present in initiatives such as training for the care of women victims of violence, as in the courses promoted since 1993 by the Feminist Collective Sexuality and Health and the Department of Preventive Medicine, USP. From this project, a booklet was published on this theme. ${ }^{23}$

From the turn of this century, many studies in Brazil documented how frequent are discriminatory and inhuman attitudes in childbirth care both in the public and the private sectors. ${ }^{24-29}$ The academic interest has expanded, and studies in recent years includes the training of providers, and more recently, population-based data, such as research by Venturi and colleagues. ${ }^{24}$ This last study, the second round of the national survey "Brazilian women and gender in public and private spaces," raised a surprising interest by the mainstream media and contributed in an unprecedented manner to the visibility of obstetric violence. According to the survey, a quarter of women who had passed through childbirth reported some form of violence in care, which was also reported by more than half of those who have undergone an abortion.

These evidences are more than eloquent about the magnitude and importance of the issue for maternal health and public health in Brazil.

\section{Definitions and terms about obstetric violence}

In Brazil, as in other Latin American countries, the term "obstetric violence" is used to describe the various forms of violence during institutional 
care to women during pregnancy, childbirth, postpartum and abortion. Other descriptors are also used for the same phenomenon, such as genderbased violence in childbirth and abortion, ${ }^{30}$ violence in childbirth, ${ }^{21,27}$ disrespect and abuse, ${ }^{31}$ cruelty in childbirth, ${ }^{15}$ inhumane/dehumanized assistance, human rights violations of women in childbirth, ${ }^{20,32,33}$ abuse, disrespect and maltreatment during childbirth, ${ }^{13}$ among other terms.

In 1993, the ground-breaking and influential Network for the Humanization of Labor and Birth (Rehuna) in its founding charter, starts from the recognition of "the circumstances of violence and harassment in which care happens" .32 However, the organization deliberately decided not to talk openly about violence, favoring terms like "humanizing childbirth", "promoting the human rights of women", fearing a hostile reaction from professionals on the charge of violence. ${ }^{32}$

A set of legal definitions of obstetric violence have been proposed, and legislation in Venezuela was the pioneer in typifying this form of violence ${ }^{34}$ :

Obstetric Violence is the appropriation of the body and reproductive processes of women by health personnel, which is expressed as dehumanized treatment, an abuse of medication, and to convert the natural processes into pathological ones, bringing with it loss of autonomy and the ability to decide freely about their bodies and sexuality, negatively impacting the quality of life of women. $^{35}$ (p. 30).

In recent years, several authors have proposed typifications and ratings on obstetric violence, including more recently the World Health Organization (WHO). ${ }^{13}$ Among several typifications obstetric violence, we believe that the synthesis made by Bowser and Hill ${ }^{31}$ in their review about the forms of abuse and disrespect has been quite explanatory, listing the main verifiable categories in the health institutions.

Based on Browser and Hill, Tesser et al., 36 in 2015, summarized the categories of disrespect linking them to the corresponding rights on the basis of a legal and social point of view, and with concrete examples of the Brazilian reality, as Table 1.

Table: Categories of disrespect and abuse, corresponding rights and examples of situations of obstetric violence

\section{Categories of \\ disrespect and abuse}

Physical abuse

Imposition of interventions without consent; interventions based on incomplete, distorted or false information

Non-confidential care, denial of privacy

Undignified care, including verbal abuse

Discrimination based on specific atributes

Abandonment, neglect or refusal to grant assistance

Detention in services

\section{Corresponding rights}

Right to be free from harm and abuse

Right to information to informed consent and refusal; right to have choices and preferences respected, including the choice of companionship during hospital stay

Right to confidentiality and privacy

Right to dignity and respect

Equality, freedon from discrimination, equitable care

Right to health care in a timely manner and to the highest attainable standard of health

Right to liberty and autonomy

\section{Examples of situations of obstetric violence}

Interventions without clinical justification just for "teaching" purposes, such repetitive vaginal exams, unnecessary caesarean sections and episiotomies, physical restraint in painful positions, practice of painful interventions without proper anesthesia, under the belief that the patient "is feeling pain anyway"

Performing episiotomy in women who verbally or in writing not authorized this intervention; disregard the birth plan without medical reasons; induction to cesarean section for misleading reasons, such as overestimation of the risks to the baby (nuchal cord, "post-term pregnancy" at the $39^{\text {th }}$ week, etc.) or to the mother (cesarean section to "prevent sexual harm," etc.); no information of potential long-term damage to those born by caesarean section (increase in chronic diseases, etc.)

Collective maternity labor wards, often without even a curtain separating the beds; claiming that lack of privacy is a justification to disrespect women 's the right to the presence of a companion (after 10 years of a national law)

Disrespectful communication with women, underestimating and mocking her pain, demoralizing their calls for help; humiliation of sexual nature, such as "when you did you liked it, so do not cry now"

Differential treatment based on attributes considered positive (married, with planned pregnancy, adult, white, better educated, middle-class, healthy, etc.), belittling those with attributes considered negative (poor, not educated, younger, black), or women who question doctors orders

Abandonment, neglect or refusal to give assistance to women who are perceived as very complainants, "uncontrolled" or plaintiffs, and in cases of incomplete abortion, deliberate delays in care to these women, with significant risks to their physical safety

In Brazil and other countries, there are reports of police arrests of pregnant women if they refuse a cesarean indicated by the doctor

Source: Adapted from Tesser, et al ${ }^{36}$ (2015), based on Bowser and Hill (2010) ${ }^{31}$ 
Causes of obstetric violence: the role of professional training professionals and of the organization of health services

The training of health professionals, especially doctors, has a key role in distortions of assistance and in the resistance to change. Hotimsky ${ }^{37}$ states that while the best evidence is updated and disseminated quickly in electronic publications available via the Internet, many medical courses have their bibliography based on outdated books, ${ }^{37}$ with little guidance to students on how to search, and appraise evidence. This means that students frequently have limited knowledge of evidencebased practice, and often deal with "best practices", "evidence-based issues" as "beliefs", "philosophy", and not as the gold standard of care. According to this author, medical practice is often apprehended in a way that is detached from its ethical dimensions, prioritizing skills at the expense of values, such as care. She describes situations in which women are objectified in favor of students' training, such as in negotiations between students and residents to perform an episiotomy for training purposes without the consent of the patient. Such understanding is frequently entrenched in the services; in other study, ${ }^{32}$ a professional interviewed, commenting on the practice of medical residents, explains: "They have to learn, and women are their teaching materials" (p.102).

According to these studies, women are selected for the "training procedures" such as episiotomies, forceps or even caesarean section, based on the patients' place in social hierarchy, ${ }^{32,36}$ exposing the existence of a sexual hierarchy, so that those women who are more vulnerable are subjected to a more rude and humiliating treatment. ${ }^{38}$ Thus, poor women, black, teenagers, those without complete antenatal care, those without a companions, sex-workers, drug users, homeless women, are those more likely to experience negligence and denial of care. The trivialization of violence against consumers relates to gender stereotypes in the training of health professionals and the organization of services. Frequent violations of human and reproductive rights of women are thereby incorporated as part of routines and sometimes do not cause any strangement. ${ }^{32}$

According to Rego et al., (2008) in medical school, patients tend to be dehumanized, deprived from their identity and transformed into a number in the hospital, a case to be studied, diagnosed and treated. ${ }^{39}$ Studies about health providers' education show that this problem, however, is not limited to obstetrics, or even just to medicine, applying in different degrees to other health professions. The whole professional education has been criticized for its failure to provide students with basic humanistic education. Thus, the provider-patient relationship is no longer between human beings, and becomes a subject-object relationship, of the doctor with the disease. ${ }^{39}$

Implications of obstetric violence to maternal morbidity and mortality

Maternal mortality is an important social and public health problem and directly reflects the quality of care. According to WHO / UNICEF: ${ }^{40}$
Maternal mortality is an indicator of women's status, access to health care and the adequacy of the healthcare system to respond to their needs. It is therefore necessary to have information on levels and trends of maternal mortality, not only for what it estimates about the risks of pregnancy and childbirth but also for what it mean for women health in general, and, by extension, their status social and economic status. (p. 481)

\section{Obstetric violence has implications on maternal mortality in the following ways:}

(1) In the additional risk associated with adverse events of aggressive management of vaginal delivery. There is potential harm associated with the use of inappropriate and excessive (also often not informed and not consented) invasive interventions in vaginal birth, such as the unregulated use of oxytocin to induce or augment labor, Kristeller maneuver, forceps, episiotomy, among others. These interventions have occurred well above of the justifiable clinical indications, as widely documented in national studies; ${ }^{41,42}$

(2) Aggressive management of childbirth works as a constraint to cesarean section, increasing its occurrence and risks. Violence in vaginal delivery is a form of coercion to elective cesarean section, ${ }^{43}$ when the options available to women boil down to this surgery, or an aggressively managed vaginal delivery, $^{44}$ not infrequently with the denial of any form of analgesia. As social movements say in Brazil, "no more violent delivery to sell cesarean" ${ }^{45}$ According to Cesar Victora, $23 \%$ of maternal deaths in Brazil can be attributed only to the increase in cesarean rates occurred since $2000^{46}$;

(3) Neglecting to assist women when they express their suffering (crying, screaming, moaning), or asking for help insistently. There is widespread culture in the services that women should behave properly, and when a woman cries or screams she should receive worse care, especially those considered "uncontrolled" or maladjusted, or those expressing any displeasure with the assistance, or insist on being assisted urgently. The delay in responding to these demands can be associated with increased risks of maternal morbidity and mortality. ${ }^{47}$

(4) In the hostility toward women (and professionals) considered to be dissidents of the hegemonic model of assistance. In cases of transfer of a birth center or a home birth, verbal abuse and delays in care tend to be higher. These cases are an example of what has been called "professional hostility" in studies conducted in other countries, ${ }^{48}$ and can be a major threat to the safety of patients;

(5) In the hostility, neglect and delay of care to women with incomplete abortions; when teams identify or assume that abortion was intentional, they often do not give it the urgent care it needs. The unavailability of services that perform abortions in situations where it is legal, also has major impact on maternal morbidity and mortality as it may lead many women to search for an unsafe abortion; ${ }^{24}$

(6) In the prohibition of the presence of a companion: most maternal deaths occur during 
delivery and postpartum (Kassebaum et al.49 (2014) and, paradoxically, in Brazil the woman lies in a health institution almost all cases. Preventing the presence of companions is a threat to women's safety, because they could signal emphatically to professionals if the clinical condition of the patient deteriorated. ${ }^{47}$ While it may be the difference between life and death and is ensured by law, this right is often not respected.

Concluding summary: how to identify, prevent and mitigate obstetric violence?

Based on the above, we present the following proposals to overcome this situation.

\section{- Interventions in the training of health providers' during undergraduation, speciali- zation and continuing education}

1. Include women's rights, and sexual and reproductive rights in undergraduate courses (medicine, nursing, midwifery, psychology, etc.) not only those rights well established in the professional codes of ethics, such as autonomy and informed choice, but also to the recent rights guaranteed by Public Health System, such as the right to companionship during hospital stay. The rights of professionals and patients, their violations and how to prevent them should be included in the entrance exams for residency and postgraduate education and in all forms of specialization. ${ }^{50}$

2. Invest in the training of midwives and obstetric nurses, the experts in physiological childbirth. ${ }^{51}$ It is unreasonable to expect that delivery care ceases to be eminently medicalsurgical, if more than $90 \%$ of births in Brazil are assisted by a doctor with training in surgery. The medical providers should be valued for their ability to make diagnosis and medical or surgical prescriptions in the minority of cases that need them, so that the majority of cases could be assisted by professionals trained for protecting normalcy ${ }^{52}$. The experience of the direct-entry Midwifery program, in the School of Arts, Sciences and Humanities (EACH-USP) can be a great starting point for replication across the country ${ }^{53}$.

3. Introduce the teaching of the physiological care and modify routines and teaching ambiences, with an emphasis on Training Birth Centers. Review of the curriculum content of all health professions to the practical teaching, to overcome the present situation of exposing the students mostly to interventions not based on scientific evidence of their safety or effectiveness (for example, women with liberally accelerated with oxytocin deliveries, in lithotomy position with the unregulated use of episiotomy and forceps, very often without companions), and in the absence of critical reflection on interventions in the classroom. Promote the teaching of the neuroendocrinology of labor and delivery, its physiological progress and its facilitation, and the promotion of maternal comfort, which also requires a change of care ambience, combined with theoretical and practical training, as well as the teaching of evidence-based guidelines. ${ }^{54}$

\section{- Interventions aimed to inform and strengthen the autonomy of women and families}

1. Provide information on childbirth care for women as parto of the antenatal care routine, so that the contents can be explored calmly in the months when the pregnancy develops. Educational activities should be part of antenatal protocols and should not be treated as an afterthought, but essential for health promotion. The use of birth plans should be promoted as a health promotion educational resource, as proposed by Tesser et al. ${ }^{36}$

2. Ensuring the right to companions: all women should be informed, in the prenatal course, about their right to companions during the hospitalization for childbirth, from admission to discharge, through labor, delivery and surgical recovery and / or anesthesia, as well as in cases of miscarriage and other complications such as ectopic pregnancy and molar pregnancy. This information must be provided in advance and with sufficient clarity so the woman and her family can make the necessary arrangements to ensure the selection and participation of companionship.

\section{- Visibilization and accountability}

1. To make the problem visible and stakeholders accountable: several institutions such as the Public Ministry, have taken responsibility to address the lack of culture of women's rights in health services, compiling complaints and calling for a dialogue on necessary changes those responsible for services and teaching institutions. Such initiatives, ignited by women's movements, were instrumental in promoting a climate of recognition of rights, hitherto unprecedented in Brazilian society, impacting public policy, such as the action against the National Health Agency (ANS) on regulation of rates cesarean from $2015.6,56$

2. To promote research and the development of indicators on obstetric violence (disrespect and abuse). In recent years, primary research and reviews of these studies have shown the importance, urgency and gaps in knowledge of this emerging theme. One of the current challenges is to develop indicators for the study of the occurrence of obstetric violence, as well as resources for measuring the effect of interventions for its prevention. These measures should include monitoring the change of the practices, routines and ambiences. ${ }^{14}$

3. To disseminate the Center for Assistance to Women - Dial 180, and train it to receive properly the complaints of obstetric violence: cases of violation of women's rights in assistance to prenatal care, childbirth, postpartum and abortion should also be forwarded to the ombudsman service and SUS, and to the Public Prosecutors.

4 - To include the assistance to miscarriage and access to safe abortion on the agenda of priorities: current focus on maternal and child policies only for women's health makes invisible the insecurity and violence in situations of miscarriage and also the difficulties of access to abortion, even in the few legal situations. The lack of services that work effectively and the use of aggressive 
techniques such as curettage - it should be replaced by intrauterine manual vacuum aspiration (MVA) are serious situations of obstetric violence, widely spread across the country, and in need of immediate intervention. ${ }^{57}$

5.Implement the Perinatal Forum, for regulation and control by society of perinatal health services: this strategy has as one of its objectives to promote dialogue between stakeholders involved in perinatal care, including the managers of public and private sectors, professionals directly linked to the service, user and organized womens' groups, training institutions, researchers, Public Defenders and Prosecutors, professional boards, among others. The creation of Perinatal Forum is a victory in itself, given the strong resistance to dialogue and change, and its implementation and strengthening as an arena for debate and establishment of pacts, have been very powerful in producing change. ${ }^{58}$

\section{REFERENCES}

1. Raiter C. Fotografia de famílias. [cited 2009May 20] Available from:http://carlaraiter.com/.

2. Bienal de Artes de São Paulo. Espaço para Abortar. MujeresCreando. São Paulo: 31a Bienal de Artes; 2014.

3. Zorzam B, Sena LM, Franzon AC, Brum K, Rapchan A. Violência obstétrica: a voz das brasileiras. [cited 2009May 20] Available from:http://docverdade.blogspot.com.br/ 2014/05/violencia-obstetrica-voz-das.html.

4. Fioretti B. Nascer no Brasil: parto, da violência obstétrica às boas práticas. DVD. Rio de Janeiro: Fiocruz; 2014.

5. Guedes LC, Rizério A, Couto NM, Cruz R. A dor além do parto. [cited 2009May 20] Available from:https://youtu.be/cIrIgx3TPWs.

6. Ministério Público Federal (MPF). MPF-SP ajuiza ação civil pública para que ANS seja obrigada a regulamentar serviços obstétricos privados.[cited 2009May 20] Available from:http://www.prsp.mpf.gov.br/sala-de-imprensa/noticias_prsp/24-08-10-2013-mpf-spajuiza-acao-civil-publica-para-que-ans-sejaobrigada-a-regulamentar-servicos-obstetricos-privados

7. CielloC, Carvalho C, KondoC, DelageD, NiyD, Werner $\mathrm{L}$, et al. Parto do princípio. Mulheres em Rede pela Maternidade Ativa. Dossiê da Violência Obstétrica "Parirás com dor". [cited 2009 May 20] Available from: http:// www.senado.gov.br/comissoes/documentos/ SSCEPI/DOC\%20VCM\%20367.pdf

8. Ministério Público Federal. Parto do Princípio e Ministério Público Federal debatem violência obstétrica com movimentos sociais de mulheres. [cited 2009 May 20] Available from:http:/ /www.prpa.mpf.mp.br/news/2014/parto-doprincipio-e-ministerio-publico-federal-debatem-violencia-obstetrica-com-movimentos-sociais-de-mulheres

9. Ministério Público de Pernambuco. Violência obstétrica: MPPE promove debate sobre atenção à saúde e mortalidade materna. [cited 2009
Obstetric violence is a complex and multifactorial public health problem, of emerging importance and high potential for explaining health challenges, and of great impact on the health of mothers and babies. The prevention and overcoming of these forms of abuse requires the engagement of all stakeholders with the assistance, demanding the necessary courage for the incorporation of innovative approaches, both to the best evidencebased care for the safety of mothers and newborns, and the promotion of their rights in health care.

\section{Declaration of responsibilities}

There has been effective participation of all related authors in this work. The final version of the manuscript was approved by all authors. There is no conflict of interest of the authors regarding this manuscript.

May 20] Available from: http://www.mppe. mp.br/mppe/index.php/comunicacao/noticias/ ultimas-noticias-noticias/4295-violenciaobstetrica-mppe-promove-debate-sobreatencao-a-saude-e-mortalidade-materna

10. Ministério Público do Estado de São Paulo. Violência Obstétrica é tema de audiência pública no MP-SP. [cited 2015 Sep 01] Available from:http://www.mpsp.mp.br/portal/page/ portal/noticias, noticia?id_noticia= 12741378\&id_grupo $=118$

11. Ministério Público Federal. MPF em São Paulo realiza audiência pública para debater episiotomia e humanização do nascimento. [cited 2015 Sep 01] Available from:http:// www.prsp.mpf.mp.br/sala-de-imprensa/ noticias_prsp/16-10-14-2013-mpf-em-saopaulo-realiza-audiencia-publica-para-debaterepisiotomia-e-humanizacao-do-nascimento

12. Ministério Público Federal. MPF/RS e MP/RS realizarão audiência pública sobre humanização da assistência ao parto. [cited 2015 Sep 01] Available from:http://noticias.pgr.mpf.mp.br/ noticias/noticias-do-site/copy_of_geral/mpf-rse-mp-rs-realizarao-audiencia-publica-sobrehumanizacao-da-assistencia-ao-parto

13. Organização Mundial da Saúde (OMS). Prevenção e eliminação de abusos, desrespeito e maus-tratos durante o parto em instituições de saúde. Genebra: OMS; 2014.

14. International Federation of Gynecology and Obstetrics. International Confederation of Midwives. White Ribbon Alliance. International Pediatric Association. World Health Organization. Mother"baby friendly birthing facilities. Int J Gynecol Obstet. 2015;128(2):95-99. DOI: http://dx.doi.org/ 10.1016/j.ijgo.2014.10.013

15. Goer H. Cruelty in maternity wards: fifty years later. J Perinat Educ. 2010;19(3):33-42. DOI: http://dx.doi.org/10.1624/105812410 X514413

16. Beech $\mathrm{BL}$, Willington S. Listen WLith Mother. [cited 2015 Sep 01] Available from:http:// 
www.aims.org.uk/Journal/Vol19No2/ editorial.htm

17. Rich A. On Lies, Secrets and Silence. Selected Prose 1966-1978. New York: Norton; 1979.

18. Doress-Worters PB, Siegal DL, Perkis R. The new ourselves, growing older. New York: Boston Women's Health Collective; 1994.

19. Boston Women's Health Book Collective. The New Ourbodies, Ourselves: a book by and for Women. New York: Touchstone Simon and Schuster; 1996.

20. Comité de América Latina y el Caribe para la Defensa de los Derechos de la Mujer - Cladem. Centro Legal para Derechos Reproductivos y Politicas Públicas(CRLP). Silencio $Y$ Complicidad: Violencia Contra Las Mujeres En Los Servicios Públicos de Salud En El Perú. Lima: Cladem/CRLP; 1998.

21. Grupo Ceres. Espelho de vênus: identidade social e sexual da mulher. Rio de Janeiro: Brasiliense; 1981.

22. Souza EM, Michaliszyn PR, Cunha MFO. Por detrás da violência: um olhar sobre a cidade, violência nas açöes de saúde. Cadernos Cefor. 1992;209.

23. Diniz CSG. O que nós como profissionais de saúde podemos fazer para promover os direitos humanos das mulheres na gravidez e no parto. São Paulo: Fundação Ford e do CREMESP; 2002.

24. Venturi G, Godinho T. Mulheres brasileiras e gênero nos espaços público e privado. São Paulo: Sesc/Fundação Perseu Abramo; 2013.

25. Aguiar JM, d'Oliveira AFPL. Violência institucional em maternidades públicas: hostilidade ao invés de acolhimento como uma questão de gênero. Tese (Doutorado) - Universidade de São Paulo. São Paulo: 2010.

26. Gomes AM de A, Nations MK, Luz MT. Pisada como pano de chão: Experiência de violência hospitalar no Nordeste brasileiro. Saúde Soc. 2008;17(1):61-72. DOI: http://dx.doi.org/ 10.1590/S0104-12902008000100006

27. Diniz CSG, Chacham AS.O "corte por cima" e o "corte por baixo": o abuso de cesáreas e episiotomias em São Paulo. Questões Saúde Reprodutiva. 2006;1(1):80-91.

28. McCallum C, Reis AP.Re-significando a dor e superando a solidão: experiências do parto entre adolescentes de classes populares atendidas em uma maternidade pública de Salvador, Bahia, Brasil. Cad Saude Publica. 2006; 22(7): 1483-91. DOI: http://dx.doi.org/10.1590/ S0102-311X2006000700012

29. Teixeira NZF, Pereira WR. Parto hospitalar: experiências de mulheres da periferia de CuibáMT.RevBrasEnferm. 2006;59(2):740-44. DOI: http://dx.doi.org/10.1590/S0034 71672006000600004

30. d'Oliveira AF, Diniz SG, Schraiber LB. Violence against women in health-care institutions: An emerging problem Lancet. 2002;359(9318):1681-5. DOI: http:// dx.doi.org/10.1016/S0140-6736(02)08592-6

31. Bowser D, Hill K. Exploring evidence for disrespect and abuse in facility-based childbirth: report of a landscape analysis. Bethesda: Harvard School of Public Health; 2010.

32. Diniz CSG, Ayres JRCM. Entre a técnica e os direitos humanos/ : possibilidades e limites da humanização da assistência ao parto. Tese (Doutorado) - Universidade de São Paulo. São Paulo: 2001.

33. Mirsky J. BirthRights: New Approaches to Safe Motherhood. London: Panos; 2007.

34. República Bolivariana de Venezuela. Leyorgánica sobre elderecho de lasmujeres a una vida libre de violência. Caracas: UNFPA; 2007.

35. Tesser CD, Knobel R, Andrezzo HF de A, Diniz SG. Violência obstétrica e prevenção quaternária/ : o que é e o que fazer.RevBrasMed Família Comunidade. 2015;10(35):1-12. DOI: http://dx.doi.org/10.5712/rbmfc10(35)1013

36. Hotimsky SN.A formação em obstetrícia: competência e cuidado na atenção ao parto. Interface Comun Saúde Educ. 2008;12(24):215. DOI:http://dx.doi.org/ 10.1590/S1414-32832008000100019

37. Mattar LD, Diniz CSG. Hierarquias reprodutivas: maternidade e desigualdades no exercício de direitos humanos pelas mulheres. Interface Comun Saúde Educ. 2012;16(40):107-20. DOI: http: / / dx.doi.org/10.1590/S 1414 32832012005000001

38. Rego S, Gomes AP, Siqueira-Batista R. Bioética e humanização como temas transversais na formação médica. RevBrasEduc Med. 2008;32(4):482-91. DOI:http://dx.doi.org/ 10.1590/S0100-55022008000400011

39. OrganizaciónPanamericana de laSalud. Revised 1990 estimates of maternal mortality: a new approach by WHO and UNICEF. Rev Panam Salud Pública. 1997;1(6):481-5. DOI: http:// dx.doi.org/10.1590/S1020-498919970006 00018

40. Leal MC, Pereira APE, Domingues RMSM, Theme Filha MM, Dias MAB, Nakamura-Pereira $M$, et al. Intervenções obstétricas durante o trabaIho de parto e parto em mulheres brasileiras de risco habitual. Cad Saúde Pública. 2014;30(Supl 1):S17-S32. DOI: http:// dx.doi.org/10.1590/0102-311X00151513

41. Diniz SG. Gênero, saúde materna e o paradoxo perinatal. Rev Bras Crescimento Desenvolv Hum. 2009;19(2):313-26.

42. Salgado HO, Niy DY, Diniz CSG. Meio grogue e com as mãos amarradas: o primeiro contato com o recém-nascido segundo mulheres que passaram por uma cesárea indesejada. RevBrasCrescimento Desenvolv Hum. 23(2):190-7.

43. Maia MB. Humanização do parto: política pública, comportamento organizacional e ethos profissional na rede hospitalar pública e privada de Belo Horizonte.Tese (Mestrado) PontifíciaUniversidade Católica de Minas Gerais. Belo Horizonte: 2008.

44. Diniz SG, d'Oliveira AFL, Lansky S. Equity and women's health services for contraception, abortion and childbirth in Brazil.Reprod Health 
Matters. 2012;20(40):94-101. DOI: http:// dx.doi.org/10.1016/S0968-8080(12)40657-7

45. Fundação Oswaldo Cruz (Fiocruz). Saúde amanhã. A saúde dos brasileiros em tempos de crise: entre a mortalidade materna e o adoecimento coletivo. [cited 2015 Sep 01] Available from:http://saudeamanha.fiocruz.br/ sa\%C3\%BAde-dos-brasileiros-em-tempos-decrise-entre-mortalidade-materna-e-oadoecimento-coletivo.

46. Rance S, McCourt C, Rayment J, Mackintosh N,Carter W, Watson K, et al. Women's safety alerts in maternity care: is speaking up enough? BMJ QualSaf. 2013;22:348-55. DOI:http:// dx.doi.org/10.1136/bmjqs-2012-001295

47. Fox D, Sheehan A, Homer C. Experiences of women planning a home birth who require intrapartum transfer to hospital: a metasynthesis of the qualitative literature. Int J Childbirth. 2014;4(2):103-19. DOI: http:// dx.doi.org/10.1891/2156-5287.4.2.103

48. Kassebaum NJ, Bertozzi-Villa A,Coggeshall MS, Shackelford KA, Steiner $\mathrm{C}$, Heuton $\mathrm{Kr}$, et al. Global, regional, and national levels and causes of maternal mortality during 1990-2013: a systematic analysis for the Global Burden of Disease Study 2013. Lancet. 2014; 384 (9947): 980-1004. DOI:http://dx.doi.org/10.1016/ S0140-6736(14)60696-6

49. Allotey PA, Diniz S, Dejong J, Delvaux T, Gruskin $S$, Fonn S. Sexual and reproductive health and rights in public health education. Reprod Health Matters. 2011;19(38):56-68. DOI: http:// dx.doi.org/10.1016/S0968-8080(11)38577-1

50. ten Hoope-Bender P. a "midwife's midwife". Lancet. 2014;384:1129-45,1146-57. DOI: http://dx.doi.org/10.1016/S01406736(14)61045-X

51. Renfrew MJ, McFadden A, Bastos MH, Campbell J, Channon AA, Cheung NF, et al. Midwifery and quality care: findings from a new evidence- informed framework for maternal and newborn care. Lancet. 2014;384(9948):1129-45. DOI: http://dx.doi.org/10.1016/S01406736(14)60789-3

52. Narchi NZ, Cruz EF, Gonçalves R. O papel das obstetrizes e enfermeiras obstetras na promoção da maternidade segura no Brasil. Cienc Saude Coletiva. 2013;18(4):1059-68. DOI: http: //dx.doi.org/10.1590/S141381232013000400019

53. Buckley SJ. Hormonal physiology of childbearing: evidence and implications for women, babies, and maternity care. Washington:Childbirth; 2015.

54. Diniz CSG, d'Orsi E, Domingues RMSM, Torres JA, Dias MAB, Schneck CA, et al. Implementação da presença de acompanhantes durante a internação para o parto: dados da pesquisa nacional nascer no Brasil. Cad Saude Publica. 2014;30(Supl.1):S140-S153. DOI: http://dx.doi.org/10.1590/0102311X00127013

55. Agência Nacional de Saúde Suplementar (ANS). Entram em vigor novas regras sobre parto na saúde suplementar.[cited 2015 Sep 01] Available from:http://www.ans.gov.br/aans/ noticias-ans/qualidade-da-saude/2923-entram-em-vigor-novas-regras-sobre-parto-nasaude-suplementar\#sthash.NcJyu68Z.dpuf.

56. Aquino EML, Menezes G, Barreto-de-Araújo TV, Alves MT, Alves SV, Almeida MCC, et al. Qualidade da atenção ao aborto no Sistema Único de Saúde do Nordeste brasileiro: o que dizem as mulheres? Cienc Saúde Coletiva. 2012; 17(7): 1765-76. DOI: http://dx.doi.org/ 10.1590/S1413-81232012000700015

57. Lansky S. Gestão da qualidade e da integralidade do cuidado em saúde para a muIher e a criança no SUS-BH/: a experiência da comissão perinatal. Rev Tempus Actas Saúde Coletiva. 2010; 4(4): 191-9.

\section{Resumo}

A violência obstétrica, descrita por diferentes termos, cada vez mais é utilizada no ativismo social, em pesquisas acadêmicas e na formulação de políticas públicas, sendo recentemente reconhecida como questão de saúde pública pela Organização Mundial da Saúde. Como tema inovador, requer um mapeamento de suas origens, definições, tipologia, impactos na saúde materna e propostas de prevenção e superação. Apresentamos esta revisão crítico-narrativasobre o tema, abarcandoliteratura acadêmica, produções dos movimentos sociais e documentos institucionais, do Brasil e exterior. Após breve recuperação histórica do tema,mapeiam-se as definições e as tipologias de violência identificadas. Discute-se a complexa causalidade destas formas de violência, incluindo o papel da formação dos profissionais e da organização dos serviços de saúde e as implicações na morbimortalidade materna. Finaliza-se com intervenções em Saúde Pública que têm sido utilizadas ou propostas para prevenir e mitigar a violência obstétrica, e uma agenda de pesquisa de inovação nesta área.

Palavras-chave: humanização do nascimento, abuso e desrespeito, violência contra a mulher, gênero e saúde, direitos humanos, direitos dos pacientes, segurança do paciente. 